\title{
Semen parameters and seminal plasma protein and biochemical profiles of dogs with benign prostatic hyperplasia after botulinum toxin type $A$ intraprostatic injection
}

\author{
Parâmetros seminais e perfis bioquímicos e proteicos do plasma seminal de cães com hyperplasia \\ prostática benigna após a administração intra-prostática de toxina botulínica tipo A
}

\author{
Tathiana Ferguson Motheo $^{\mathrm{I}^{*}}$ Aracélle Elisane Alves ${ }^{\mathrm{I}}$ Giuliano Queiroz Mostachio ${ }^{\mathrm{I}}$ \\ Maricy Apparício ${ }^{\mathrm{I}}$ Alexandre Pinto Ribeiro ${ }^{\mathrm{II}}$ Fabiana Ferreira de Souza ${ }^{\mathrm{II}}$ \\ Maria Denise Lopes ${ }^{\mathrm{III}}$ Wilter Ricardo Russiano Vicente $^{\mathrm{I}}$
}

\section{ABSTRACT}

This study aimed to determine the effects of different concentrations of botulinum toxin type A (BT-A) on semen parameters, and seminal plasma biochemical and protein profiles of dogs with benign prostatic hyperplasia (BPH). Eighteen sexually intact male dogs with $B P H$ were randomly divided in three groups, and received an intraprostatic injection of saline solution (control group - CG), 250UI (GI) or 500UI (GII) of BT-A under transabdominal ultrasound guidance. Semen was collected at baseline, 2, 4 and 8 weeks after treatment. Semen parameters were determined and seminal plasma $\mathrm{pH}$, total protein (TP), total chlorides (TC), calcium (Ca), potassium (K), and sodium ( $\mathrm{Na}$ ) concentrations were assessed. One-dimensional sodium dodecyl sulfatepolyacrilamide gel eletrophoresis (SDS- PAGE) was performed to determine seminal plasma protein profile. Sperm parameters and seminal plasma $\mathrm{pH}, \mathrm{TP}, \mathrm{TC}, \mathrm{Ca}$ and $\mathrm{K}$ mean values did not change significantly at any time point and among treated groups $(P>0.05)$. The SDS-PAGE analysis of the pooled fractions identified 31 protein bands with molecular weights ranging from 3.9 to $106.2 \mathrm{kDA}$ in all treatment groups during the entire evaluation period. Regardless the used dose, intraprostatic BT-A injection do not alter semen parameters and seminal plasma biochemical and protein profiles of dogs with $B P H$.

Key words: botulinum toxin, prostate, seminal plasma, dog.

RESUMO

O objetivo do presente estudo foi determinar a ação de diferentes concentrações de toxina botulínica tipo A (TB-A) sobre os parâmetros seminais, perfis bioquímicos e proteicos do plasma seminal de cães com hiperplasia prostática benigna (HPB). Dezoito cães hígidos, não orquiectomizados com HPB foram divididos em três grupos, os quais foram submetidos à injeção intra-prostática de solução salina (grupo controle -
GC), $250 U I$ (GI) ou $500 U I$ (GII) de TB-A. Amostras seminais foram coletadas previamente aos tratamentos e após 2, 4 e 8 semanas. Os parâmetros seminais assim como os valores de $\mathrm{pH}$ e concentrações de proteínas totais (TP), cloretos totais (CT), cálcio (Ca), potássio (K), sódio (Na) do plasma seminal foram mensurados após as coletas. O perfil proteico do fluido prostático foi estabelecido por meio de eletroforese SDS-PAGE. Não foram constatadas diferenças significativas quanto aos parâmetros espermáticos e perfil bioquímico do plasma seminal intragrupos e intergrupos $(P>0,05)$. À SDS-PAGE foram identificadas 31 bandas proteicas com pesos moleculares de 3,9 a 106,2kDA, em todos os tratamentos e durante todo o período de avaliação. Dessa forma, concluiu-se que, independentemente da dose utilizada, a injeção intra-prostática de TB-A não altera os parâmetros seminais, assim como os perfis bioquímico e proteico do plasma seminal de cães com HPB.

Palavras-chave: toxina botulínica, próstata, plasma seminal, cão.

\section{INTRODUCTION}

Benign prostatic hyperplasia $(\mathrm{BPH})$ is one of the most common and prevalent age-related diseases in men and sexually intact male dogs (VERHAMME et al., 2002). There are typically no clinical signs of canine BPH displayed until the condition has progressed to the point that the enlarged prostate causes tenesmus and/or serosanguineous urethral discharge. Other clinical signs may include dysuria, hemospermia, or rarely a stilted gait secondary to prostatic pain (SMITH, 2008).

\footnotetext{
'Departamento de Reprodução Animal, Faculdade de Ciências Agrárias e Veterinária (FCAV), Universidade Estadual Paulista (Unesp), 14884-900, Jaboticabal, SP, Brasil. E-mail: tfmotheo@gmail.com.*Autor para correspondência.

"Departamento de Clínica Médica Veterinária, Faculdade de Agronomia e Medicina Veterinária, Universidade Federal de Mato Grosso (UFMT), Cuiabá, MT, Brasil.

IIIDepartamento de Reprodução Animal, Faculdade de Medicina Veterinária e Zootecnia (FMVZ), Unesp, Botucatu, SP, Brasil. Received 04.12.13 Approved 11.21.13 Returned by the author 03.20.14 CR-2013-0505.R1
} 
In dogs, bilateral orchiectomy is the treatment of choice, yet in breeders and in poor surgical candidates, medical therapy should be considered (SMITH, 2008). The most widely prescribed medications for canine BPH include antiestrogenic and estrogenic compounds, synthetic progestins, antiandrogens, $5 \alpha$-reductase inhibitors, agonists and antagonists of GnRH. However, most of them are not exempt of adverse effects and may lead to aplastic anemia, testicular degeneration, decrease on semen volume, sperm concentration, total and progressive sperm motility, percentage of morphologically normal spermatozoa and/or anejaculation (SMITH, 2008; LIMMANONT et al., 2012).

The prostatic function is under the influence of autonomic innervation and acetylcholine stimulates the gland secretion and growth, and noradrenaline induces prostatic contraction (PENNEFATHER, 2000). Botulinum toxin type A (BT-A) inhibits the release of acetylcholine into the synaptic junction decreasing the muscle tone in skeletal and smooth muscles (CHANCELLOR et al., 2008).

Studies performed in rats (SILVA et al., 2009), dogs (CHUANG et al., 2006) and men (KUO, 2005; BRISINDA et al., 2011) have been developed using BT-A for BPH treatment. However, most of them assessed only the symptomatic and clinical improvement post-treatment, not considering the effects on semen quality.

Recently, our research group described that 250UI BT-A treatment did not affect the libido and semen quality in dogs with BPH (MOSTACHIO et al., 2012). Thus, considering that sperm function is highly dependent on ionic and protein environment (HAMAMAH \& GATTI, 1998) and seminal plasma plays an important role on in vivo fertility (SOUZA et al., 2007) we hypothized if BT-A treatment could cause changes on the seminal plasma ionic and protein profiles of dogs with BPH. Therefore, we aimed to assess sperm parameters of dogs treated with a higher therapeutic concentration of BT-A, and focused on determining if different concentrations of BT-A could alter the seminal plasma biochemical and protein profiles in dogs treated with BT-A.

\section{MATERIAL AND METHODS}

Eighteen healthy mixed breed sexually intact male dogs (5-9 years old), weighting $15-25 \mathrm{~kg}$ were used in this study. The animals were selected based on a standard evaluation for BPH, which comprised a prostatic digital rectal inspection, prostatic fluid assessment, and radiographic and ultrasonographic imaging of the prostate gland. Therefore, all dogs presented an enlarged, symmetrical and smooth prostate with distinct dorsal medium raphe with absence of pain per rectum palpation. The prostatic fluid revealed absence of inflammatory cells and organisms and had prostatic diameter on the lateral radiographic projection greater than $70 \%$ of the distance between the sacral promontory and the pubis, and/or the prostatic volume measured ultrasonographically greater than $15 \mathrm{~cm}^{3}$. Most patients presented clinical signs of $\mathrm{BPH}$, however those with serosanguineous discharge were excluded from the experiment.

Before BT-A(Dysport ${ }^{\circledR}$, Aché Laboratórios Farmacêuticos S/A, Brazil) injection all patients were fastened. The dogs were sedated with $1 \mathrm{mg} \mathrm{kg}^{-1}$ of levomepromazine (Neozine, Sanofi-Aventis, Brazil) and $2 \mathrm{mg} \mathrm{kg}^{-1}$ of tramadol (Traman,Cristália, Brazil) intramuscularly. After 15 minutes, the patients were induced intravenously with $5 \mathrm{mg} \mathrm{kg}^{-1}$ of propofol (Propovan, Cristália, Brazil), subsequently intubated and maintained under inhalant anesthesia with isofluorane (Isoforine, Cristália, Brazil). In dorsal recumbency, transabdominal ultrasonography using a $7.5 \mathrm{MHz}$ sectorial transducer was performed and the prostate gland identified. Dogs were randomly divided in three groups (6 animals/group), which received intraprostatic injection of $4 \mathrm{ml}$ of $0.9 \% \mathrm{NaCl}$ normal saline solution (Control Group - CG) or 250UI (Group I - GI) or 500UI (Group II -GII) of BT-A. A 21 -gauge spinalneedle $(0.8 \times 100 \mathrm{~mm})$ was introduced into the central part of each prostatic lobe, and the respective solutions of each group were injected. Concentrations of 250UI and 500UI of BT-A were obtained by diluting each vial in saline solution.

Before treatments, the dogs were housed during 4 to 6 weeks for semen collection. One ejaculate per animal was collected in the absence of a teaser bitch by digital manipulation. The entire second and third fractions were collected before, 2, 4, and 8 weeks following the injection of BT-A or saline solution. Semen analysis was carried out immediately after collection. The volume was determined using a graduated plastic tube and sperm total motility and vigor were subjectively estimated using a phase contrast microscope at 200x. Motility (0-100\%) was estimated in increments of $5 \%$ and vigor was scored on a scale 0-5. Sperm count was performed using a Neubauer hemocytometer chamber under a phase contrast microscope at 200x. For sperm morphology, semen smears were fixed and stained by a modified KARRAS staining method (PAPA et al, 1988). For each ejaculate, 200 spermatozoa were evaluated under 
phase contrast microscope at 100x magnification and classified as normal or with minor or major defects.

To assess membrane integrity semen samples were submitted to the hyposmotic swelling test (CUNHA, 2008) and to the propidium iodide (PI) and 6-carboxyfluorescein diacetate (CDI) staining (HARRISON \& VICKERS, 1990). For the hyposmotic swelling test a total of 200 spermatozoa were evaluated under a phase contrast microscope and the number of coiled tail spermatozoa was recorded. For fluorescent staining 200 spermatozoa were evaluated at $400 \mathrm{x}$ magnification with an epifluorescence microscope (Olympus, USA). Fluorescent green sperm cells were considered intact and red or red/green sperm cells were considered damaged.

After analysis, the ejaculates were centrifuged (800xg for 20min) and the seminal plasma was examined microscopically to confirm the absence of sperm cells and then stored at $-20^{\circ} \mathrm{C}$. Seminal plasma total protein (TP), chlorides (CL), calcium $(\mathrm{Ca})$, potassium $(\mathrm{K})$ and sodium $(\mathrm{Na})$ were assessed with commercial kits (Labtest Diagnostica, Brazil) using an electrolyte analyzer (Iselab Eletrolyte Analyser, Brazil) to determine seminal plasma concentrations of each element. Samples hydrogenion concentration $(\mathrm{pH})$ was measured by a $\mathrm{pH}$ meter (Digimed, Brazil).

The protein profile was determined by onedimensional sodium dodecyl sulfatepolyacrilamide gel electrophoresis - SDS-PAGE (Mini VE, Amershan Biosciences, Sweden) mini-gels using two concentrations of polyacrylamide (12 and 18\%). The total amount of protein used to load each well was $80 \mu \mathrm{g}$ in $20 \mu \mathrm{L}$ and $16 \mu \mathrm{g}$ in $10 \mu \mathrm{L}$ respectively for $12 \%$ and $18 \%$ gels. Each gel was loaded with a protein molecular weight standard (Full Range Rainbow, Recombinant Protein Molecular Weight Marker, 10$250 \mathrm{kDa}$ and Rainbow Colored Protein Molecular Weight Marker, 2.5-45kDa; Amershan Biosciences, Sweden). Subsequently, the mini gels were stained with Coomasie Blue R-250. Molecular weight (MW) and integrated optical density (IOD) of the protein band were assessed using an image analysis software (VDS, Image Master Plus, Amershan Biosciences, Sweden).

Statistical analysis was performed using Prisma (Prism 4.0, GraphPad Software inc - San Diego, CA, USA). One way repeated measures ANOVA followed by Tukey's multiple comparison test were used for all parameters to compare means at baseline and 2, 4 and 8 weeks after injection of saline solution or BT-A and among treatment groups.

\section{RESULTS AND DISCUSSION}

Prostatic biopsy is the gold standard method for definitive diagnosis of BPH. Once we aimed to determine the protein and biochemical profile of seminal plasma, the biopsy of the gland could eventually cause changes in the composition of the prostatic fluid. Nevertheless, for the same reason we excluded dogs with clinical signs of serosanguineous discharge. Therefore, BPH was determined by a presumptive diagnosis based on other clinical signs, physical examination, assessment of the prostatic fluid, and on detection of a uniform prostatic enlargement by rectal inspection, radiography, and ultrasonography imaging and measurement.

Botulinum toxin type $\mathrm{A}$ is the strongest biological neurotoxin known to man, however in our study, as well as in previous ones the therapeutic use of BT-A for BPH treatment showed to be safe and easy to perform (BRISINDA et al., 2011; MOSTACHIO et al., 2012). In previous studies, intraprostatic injection of 100UI and 200UI of Botox induced prostate atrophy and apoptosis in dogs (CHUANG et al., 2006) and relieved bladder outlet obstruction and improved clinical symptoms in men (CHUANG et al., 2005; KUO, 2005). ROSALES (2006) described a conversion ratio of Botox: Dysport of 1:2.5 and once 250UI BT-A (Dysport) treatment did not cause changes on semen parameters (MOSTACHIO et al., 2012) we opted by using the same BT-A concentration, as well as a higher therapeutic dosage of 500UI of Dysport to compare semen parameters data and to assess seminal plasma ionic and protein profiles.

Regardless the type of treatment, sperm volume, progressive motility, vigor, sperm morphology, hyposmotic-swelling test and fluorescent staining did not change significantly during the evaluated periods and maintained in the normal range described for the canine species $(\mathrm{P}>0.05)$. Despite no significant differences among groups, sperm concentration increased significantly over the eight weeks of treatment in all groups $(\mathrm{P}=0.018)$ (Table 1). However, we presume that these findings are not linked to the treatments used in this study, but may suggest a failure on conditioning these animals for semen collection.

Seminal plasma plays an important role in sperm maturation by enzymatic processes and by modifying the sperm surface. It contains a wide variety of biochemical components, many of which are specific for regulation of sperm function (PÉREZPÉ, 2001). Therefore, we hypothesized if semen ionic environment could be compromised after BT-A 
Table 1 - Mean values of volume (V), sperm concentration (Conc.), sperm motility (Motility), sperm vigor (0-5), morphologically normal spermatozoa (Norm. sptz.), hyposmotic swelling test (Hyp.), and fluorescent probes (Fluo.) from dogs of the control (CG- saline solution), group I (GI - 250UI BT-A) and group II (GII - 500UI BT-A) at baseline (0) and at 2, 4, and 8 weeks after treatment.

\begin{tabular}{|c|c|c|c|c|c|c|c|c|}
\hline Group & Period (weeks) & $\mathrm{V}(\mathrm{mL})$ & Conc. $\left(\times 10^{6}\right)$ & Motility (\%) & Vigor (0-5) & Norm. sptz (\%) & Hyp. (\%) & Fluo. (\%) \\
\hline \multirow{4}{*}{ CG } & 0 & $4.7 \pm 0.3$ & $141 \pm 20.2$ & $86 \pm 3.3$ & $3.7 \pm 0.3$ & 86 & $96 \pm 0.9$ & 97 \\
\hline & 2 & $4.5 \pm 0.9$ & $155 \pm 39.7$ & $84 \pm 2.1$ & 4 & 88 & $94 \pm 2$ & 96 \\
\hline & 4 & $4.6 \pm 0.3$ & $248 \pm 29$ & $89 \pm 2.0$ & $4.7 \pm 0.3$ & 89 & $95 \pm 1.8$ & 94 \\
\hline & 8 & $5 \pm 0.3$ & $222 \pm 40.5$ & $85 \pm 2.9$ & $4.3 \pm 0.3$ & 88 & $96 \pm 0.3$ & 97 \\
\hline \multirow{4}{*}{ G1 } & 0 & $5.5 \pm 0.9$ & $161 \pm 42$ & $88 \pm 2.6$ & $4 \pm 0.4$ & 85 & $96 \pm 1.5$ & 99 \\
\hline & 2 & $3.8 \pm 1.1$ & $239 \pm 60.4$ & $91 \pm 1.7$ & $4.2 \pm 0.2$ & 87 & $97 \pm 0.9$ & 99 \\
\hline & 4 & $4 \pm 0.7$ & $339 \pm 107.2$ & $89 \pm 3.2$ & $4 \pm 0.3$ & 89 & $95 \pm 2.4$ & 94 \\
\hline & 8 & $4.6 \pm 1.4$ & $266 \pm 102.4$ & $89 \pm 2.7$ & $4.4 \pm 0.2$ & 87 & $96 \pm 1.3$ & 92 \\
\hline \multirow{4}{*}{ G II } & 0 & $4.3 \pm 1.2$ & $178 \pm 20.2$ & $87 \pm 1.8$ & $4.0 \pm 0.1$ & 80 & $94 \pm 2.5$ & 96 \\
\hline & 2 & $4.3 \pm 0.4$ & $212 \pm 41.1$ & $82 \pm 3.2$ & 3.8 & 81 & $95 \pm 1.2$ & 95 \\
\hline & 4 & $4.4 \pm 0.6$ & $227 \pm 17.5$ & $89 \pm 1.8$ & $4.1 \pm 0.1$ & 83 & $93 \pm 2.6$ & 93 \\
\hline & 8 & $4.2 \pm 0.5$ & $231 \pm 21.1$ & $90 \pm 2.2$ & $4.3 \pm 0.2$ & 82 & $97 \pm 1.2$ & 95 \\
\hline $\mathrm{P}$ & & 0.99 & 0.018 & 0.23 & 0.23 & 0.7 & 0.41 & 0.76 \\
\hline
\end{tabular}

treatment. Thus, we assessed $\mathrm{pH}$ values, $\mathrm{TP}, \mathrm{Cl}, \mathrm{Ca}$, $\mathrm{K}$ and $\mathrm{Na}$ concentrations on the prostatic fluid and no differences where noticed among time points or groups (Table 2). Despite slight differences from the data described in previous reports, the values maintained on the normal range for the canine species (SOUZA, 2003).

Assessing the electrophoretic profile of seminal plasma proteins, in the $12 \%$ polyacrylamide mini-gels a total of 20 protein bands were identified in the seminal plasma of all animals. The molecular weight (MW) ranged from 106.2 to $16.6 \mathrm{kDa}$, and only two protein bands $(50 \mathrm{kDa}$ and $33.8 \mathrm{kDa})$ were present in all animals at baseline, and at 2, 4 and 8 weeks after injection of saline solution or BT-A. In the $18 \%$ polyacrylamide mini-gels 10 protein bands were recorded. The molecular weights ranged from 15.2 to $3.9 \mathrm{kDa}$, and two protein bands $(15.2 \mathrm{kDa}$ and $13.2 \mathrm{kDa})$ were present in all samples, during the entireevaluation period. One third of the proteins showed MW below $16 \mathrm{kDa}$ and among them the $15.2 \mathrm{kDa}$ protein band presented higher expression.

Table 2 - Mean values of seminal plasma total protein $\left(\mathrm{gdL}^{-1}\right)$, chlorides $\left(\mathrm{mmoldL}^{-1}\right)$, calcium $\left(\mathrm{mmoldL}^{-1}\right)$, sodium $\left(\mathrm{mmoldL}^{-1}\right)$, potassium (mmoldL ${ }^{-1}$ ) concentration and $\mathrm{pH}$ from dogs of the control (CG- saline solution), group I (GI - 250UI BT-A) and group II (GII 500UI BT-A) at baseline (0) and at 2, 4, and 8 weeks after treatment.

\begin{tabular}{|c|c|c|c|c|c|c|c|}
\hline Group & $\begin{array}{l}\text { Period } \\
\text { (weeks) }\end{array}$ & $\begin{array}{l}\text { Total protein } \\
\left(\mathrm{g} \mathrm{dL}^{-1}\right)\end{array}$ & $\begin{array}{l}\text { Chlorides } \\
\left(\mathrm{mmol} \mathrm{dL}^{-1}\right)\end{array}$ & $\begin{array}{l}\text { Calcium } \\
\left(\mathrm{mg} \mathrm{dL}^{-1}\right)\end{array}$ & $\begin{array}{l}\text { Sodium } \\
\left(\mathrm{mmol} \mathrm{dL}^{-1}\right)\end{array}$ & $\begin{array}{l}\text { Potassium } \\
\left(\mathrm{mmol} \mathrm{dL}^{-1}\right)\end{array}$ & $\mathrm{pH}$ \\
\hline \multirow{4}{*}{$\mathrm{CG}$} & 0 & 2.3 & 122 & 1.9 & 144.7 & 8.1 & 6.1 \\
\hline & 2 & 2.7 & 121.3 & 2.6 & 143.8 & 8.5 & 6.1 \\
\hline & 4 & 1.9 & 128.3 & 0.9 & 142.2 & 9.1 & 6.1 \\
\hline & 8 & 4.5 & 131.3 & 1.5 & 141.5 & 9 & 6.4 \\
\hline \multirow{4}{*}{ GI } & 0 & 2 & 157.7 & 0.9 & 141.8 & 7.5 & 6.1 \\
\hline & 2 & 2.8 & 112.2 & 1.3 & 1401 & 7.8 & 6.2 \\
\hline & 4 & 3 & 111.2 & 1.3 & 140.3 & 8.9 & 6.3 \\
\hline & 8 & 2.4 & 102.8 & 1.5 & 142.5 & 8.9 & 6.4 \\
\hline \multirow{4}{*}{ GII } & 0 & 2.3 & 141.4 & 2.3 & 146.8 & 8.8 & 6.3 \\
\hline & 2 & 2.9 & 124.8 & 1.9 & 145.3 & 8.8 & 6.3 \\
\hline & 4 & 2.8 & 151.7 & 1.8 & 144 & 8.6 & 6.3 \\
\hline & 8 & 2.9 & 131.7 & 1.9 & 144.7 & 8.5 & 6.3 \\
\hline $\mathrm{P}$ & & 0.50 & 0.09 & 0.14 & 0.64 & 0.10 & 0.97 \\
\hline
\end{tabular}


Similarly to the described by MARTINS (2005) we identified the 31 bands, however the MW recorded in our study $(100.6$ to $3.6 \mathrm{kDa})$ resembled the ones expressed by SOUZA (2003). Notwithstanding, the same author described $85 \%$ of the bands with MW below $17 \mathrm{kDa}$, differently from the $30 \%$ found in our study. We believe that the incongruity on the results could have been due to the different concentrations of the separating gels (12 and $18 \%$ versus $13 \%$ and $22 \%$ ) that may have influenced the location of protein bands.

Proteins of the seminal plasma have an ample panorama of action, and some appearresponsible for establishing fertility (RODRÍGUEZ-MARTÍNEZ et al., 2011). Arginine esterase, also known as canine prostate specific protein (CPSE) is a protein with enzymatic activity that is found in high concentrations in the canine prostatic fluid and has been associated with fertility (MCENTEE et al., 1987; SOUZA et al., 2006). Previous reports suggested that the $15 \mathrm{kDa}$ band may be a subunit of the arginine esterase (SOUZA, 2003). We identified 25 a $15.2 \mathrm{kDa}$ band, and assessing the integrated optic density (IOD) we observed that this parameter did not change significantly among treatment-groups and time points (Table 3). Thus, if indeed this protein band is a subunit of the CPSE the BT-A treatment do not affect on its function regardless the used dosage.

\section{CONCLUSION}

The intraprostatic injection of 250UI or $500 \mathrm{UI}$ of BT-A do not alter semen parameters and seminal plasma biochemical and protein profiles of dogs with BPH after 8 weeks of treatment. It is therefore a promising and effective alternative to traditional treatment for $\mathrm{BPH}$, specially in breeders and in poor surgical candidates, however, further

Table 3 - Mean \pm standard error of mean (SEM)* of integrated optic density (OID) of the $15.2 \mathrm{kDa}$ band of the canine seminal plasma from dogs of the control (CG- saline solution), group I (GI - 250UI BT-A) and group II (GII - 500UI BT-A) at baseline (0) and at 2, 4, and 8 weeks after treatment.

\begin{tabular}{llll}
\hline $\begin{array}{l}\text { Periods } \\
\text { (weeks) }\end{array}$ & \multicolumn{1}{c}{ CG } & \multicolumn{1}{c}{ GI } & \multicolumn{1}{c}{ GII } \\
\hline 0 & $222.2 \pm 26.5$ & $128 \pm 72.4$ & $279.1 \pm 52$ \\
2 & $226.7 \pm 29$ & $158.6 \pm 66.9$ & $244.3 \pm 91.1$ \\
4 & $203.3 \pm 28.5$ & $158.3 \pm 36.4$ & $234.1 \pm 79$ \\
8 & $114.5 \pm 17.4$ & $136.9 \pm 81.2$ & $359.9 \pm 38.1$ \\
\hline
\end{tabular}

*ANOVA $(\mathrm{P}=0.073)$. studies evaluating pregnancy rates, quality of the embryos and the viability of the offspring from females mated or inseminated with sperm from males treated with BT-A would be essential for assessing in vivo fertility of patients submitted to this treatment.

\section{ACKNOWLEDGEMENTS}

We thank Fundação de Amparo à Pesquisa do Estado de São Paulo (FAPESP) for funding this research (2006/59242-0).

\section{BIOETHICS AND BIOSSECURITY COMMITTEE APPROVAL}

Protocol number: 009155-07

\section{REFERENCE}

BRISINDA, G. et al. Treating benign prostatic hyperplasia with botulinum neurotoxin. Current Medicinal Chemistry, v.18, p.3468-3475, 2011. Available from: <http://www. eurekaselect.com/74756/article>. Accessed: Sept. 15, 2013. doi: $10.2174 / 092986711796642481$

CHANCELLOR, M.B. et al. Drug insight: biological effects of botulinum toxin $\mathrm{A}$ in the lower urinary tract. Nature Reviews Urology, v.5, p.319-328, 2008. Available from: <http://www. nature.com/nrurol/journal/v5/n6/full/ncpuro1124.html $>$. Accessed: Jul. 18, 2012. doi:10.1038/ncpuro1124.

CHUANG, Y.C. et al. Botulinum toxin type A improves benign prostatic hyperplasia symptoms in patients with small prostates. Urology, v.66, p.775-779, 2005. Available from: <http://www. goldjournal.net/article/S0090-4295(05)00532-7/abstract $>$. Accessed: Jul. 18, 2012. doi: 10.1016/j.urology.2005.04.029.

CHUANG, Y.C. et al. Intraprostatic injection of botulinum toxin type-A relieves bladder outlet obstruction in human and induces prostate apoptosis in dogs. BMC Urology, v.6, n.12, p.1-6, 2006. Available from: <http://www.biomedcentral.com/1471-2490/6/12>. Accessed: Jul. 18, 2012. doi: 10.1186/1471-2490-6-12.

CUNHA, I.C.N. Breeding soundness evaluation of male dog. Journal Brasileiro de Ciência Animal, v.1, p.49-65, 2008. Available from: <http://www.jbca.com.br/v1n1/artigo5/5_exame_ andrologico_no_cao.pdf>.Accessed: Jul. 18, 2012.

HARRISON, R.A.P.; VICKERS, S.E. Use of fluorescent probes to assess membrane integrity in mammalian spermatozoa. Journal of Reproduction and Fertility, v.88, p.343-352, 1990. Available from: $<$ http://www.reproduction-online.org/content/88/1/343.short $>$. Accessed: Jul. 18, 2012. doi: 10.1530/jrf.0.0880343.

HAMAMAH, S.; GATTI, J.C. Role of the ionic environment and internal $\mathrm{pH}$ on sperm activity. Human Reproduction, v.13, p.20-30, 1998. Available from: <http://humrep.oxfordjournals.org/ content/13/suppl_4/20.full.pdf +html>. Accessed: Jul. 18, 2012. doi: 10.1093/humrep/13.suppl_4.20.

KUO, H.C. Prostate botulinum A toxin injection - an alternative treatment for benign prostatic obstruction in poor surgical candidates. Urology, v.65, p.670-674, 2005. Available from: $<$ http:// www.sciencedirect.com/science/article/pii/S0090429504013342>. Accessed: Jul. 18, 2012.doi: 10.1016/j.urology.2004.10.077. 
LIMMANONT, C. et al. Effect of finasteride and deslorelin treatment on clinical signs, prostatic volume and semen quality in dogs with benign prostatic hypertrophy: a clinical trial. Kasetsart Journal: Natural Science, v.46, p.724-735, 2012. Available from: <http://kasetsartjournal.ku.ac.th/kuj_files/2012/ A1212191516168881.pdf>. Accessed: Jul. 18, 2012.

MARTINS, M.I.M. Efeito da sazonalidade sobre a função testicular de cães. 2005. 123f. Tese (Doutorado em Reprodução Animal) - Curso de Pós -graduação em Medicina Veterinária, Universidade Estadual Paulista, SP.

MCENTEE, M. et al. Adenocarcinoma of the canine prostate: immunohistochemical examination for secretory antigens. Prostate, v.11, p.163-170, 1987. Available from: $<$ http://www. ncbi.nlm.nih.gov/pubmed/2444955>. Accessed: Jan. 21, 2013.

MOSTACHIO, G.Q. et al. Intraprostatic injection of botulinum toxin type A in treatment of dogs with spontaneous benign prostatic hyperplasia. Animal Reproduction Science, v.133, p.224-228, 2012. Available from: <http://www.animalreproductionscience com/article/S0378-4320(12)00203-5/abstract>. Accessed: Jan. 21, 2013. doi: 10.1016/j.anireprosci.2012.06.024.

PAPA, F.O. et al. Coloração espermática segundo Karras modificado pelo emprego do Barbatimão (Sthyphnodendrumbarbatiman). Arquivo Brasileiro de Medicina Veterinária e Zootecnia, v. 40, p.115-123, 1988 .

PENNEFATHER, J.N. The autonomic and sensory innervation of the smooth muscle of the prostate gland: a review of pharmacological and histological studies. Journal of Autonomic Phamacology, v.20, p.193-206, 2000. Available from: <http://onlinelibrary.wiley. com/doi/10.1046/j.1365-2680.2000.00195.x/abstract>. Accessed: Jul. 18, 2012. doi: 10.1046/j.1365-2680.2000.00195.x.

PÉREZ-PÉ, R. Semen plasma proteins prevent cold-shock membrane damage to ram spermatozoa. Theriogenology, v.56, p.425-434, 2001. Available from: $<\mathrm{http}$ ://www.sciencedirect.com/ science/article/pii/S0093691X0100574X>. Accessed: Jul. 18, 2012. doi:10.1016/S0093-691X(01)00574-X.

RODRÍGUEZ - MARTÍNEZ, H. et al. Seminal plasma proteins: what role do they play? American Journal of Reproductive Immunology, v.66, S1, p.11-22, 2011. Available from: <http:// onlinelibrary.wiley.com/doi/10.1111/j.1600-0897.2011.01033.x/ full>. Accessed: Jul. 18, 2012. doi: 10.1111/j.16000897.2011.01033.x.

ROSALES, R.L. et al. Pharmacology of botulinum toxin: differences between type A preparation. European Journal of Neurology, v.13, n.S1, p.2-10, 2006. Available from: <http:// onlinelibrary.wiley.com/doi/10.1111/j.1464-410X.2011.10926.x/ abstract $>$. Accessed: Jul. 18, 2012. doi: 10.1111/j.1464410X.2011.10926.x

SILVA, J. et al. Mechanisms of prostate atrophy after glandular botulinum neurotoxin type a injection: an experimental study in the rat. European Urology, v.56, n.1, p.134-141, 2009. Available from: $<$ http://www.sciencedirect.com/science/article/pii/ S0302283808008245>. Accessed: Apr. 03, 2013. doi: 10.1016/j. eururo.2008.07.003

SMITH, J. Canine prostatic disease: A review of anatomy, pathology, diagnosis, and treatment. Theriogenology, v.70, p.375-383, 2008. Available from: <http://www.ncbi.nlm.nih.gov/ pubmed/18514299>. Accessed: Jul. 18, 2012. doi: 10.1016/j. theriogenology.2008.04.039.

SOUZA, F.F. Caracterização eletroforética das proteínas e análise bioquímica do plasma seminal canino. 2003. 98f. Tese (Doutorado em Reprodução Animal) - Curso de Pós-graduação em Medicina Veterinária, Universidade Estadual Paulista, SP.

SOUZA, F.F. et al. Heparin-binding proteins of canine seminal plasma. Theriogenology, v.66, p.1606-1609, 2006. Available from: <http:// www.sciencedirect.com/science/article/pii/S0093691X06001129>. Accessed: Jul. 18, 2012. doi: 10.1016/j.theriogenology.2006.02.016.

SOUZA, F.F. et al. Characteristics of seminal plasma proteins and their correlation with canine semen analysis. Theriogenology, v.68, p.100-106, 2007. Available from: <http://www.sciencedirect. com/science/article/pii/S0093691X07001641>. Accessed: Jul. 18, 2012. doi: 0.1016/j.theriogenology.2006.11.016.

VERHAMME, K.M. et al. Incidence and prevalence of lower urinary tract symptoms suggestive of benign prostatic hyperplasia in primary care - the Triumph project. European Urology, v.42, p.323-332, 2002. Available from: <http://www.sciencedirect.com/ science/article/pii/S0302283802003548> . Accessed: Jul. 18, 2012. doi: 10.1016/S0302-2838(02)00354-8. 